\title{
PENDIDIKAN POLITIK DAN PEMBENTUKAN KELOMPOK PENGAWAS DANA DESA
}

\author{
Faqih Alfian $^{1)}$ dan Taufik Akbar ${ }^{2)}$ \\ ${ }^{1,2}$ Program Studi Ilmu Politik, Fakultas Ilmu Sosial dan Ilmu Politik, Universitas Brawijaya Malang \\ Email: alfaqih99@ub.ac.id,takbar@ub.ac.id
}

\begin{abstract}
Abstrak
Pendidikan merupakan salah satu sarana untuk mentransfer pengetahuan. Dengan berbagai media yang dipakai, diharapkan mampu memberikan informasi yang diharapkan. Pendidikan politik salah satunya, dengan harapan masyarakat paham dan mengerti apa yang dimaksud dengan politik. Terlebih pada masyararkat desa yang kecenderungan memiliki minim informasi akan politik. Dalam kegiatan ini, pendidikan politik memakai metode andragogi, dimana pembelajaran yang dikhususkan untuk orang dewasa. Mengajak masyarakat untuk berperan aktif dalam permasalahan yang ada. Focus Group Discussion menjadi salah satu wahana dalam pelibatan masyarakat, mereka dapat menyampaikan pendapat maisng-masing. Sasaran utama dalam kegiatan ini adalah kelompok pemuda. Hasil pengabdian adalah: 1. Penyelenggaraan "Pendidikan Politik dan Pembentukan Kelompok Pengawas Dana Desa" berangkat dari dua hal, yakni pertama mengenai urgensi Partisipasi masyarakat dalam pemerintahan desa. Kedua, berangkat dari keprihatinan terhadap kecenderungan apatis masyarakat dalam pengelolahan dana desa, 2. Proses penyelenggaraan pengabdian ini dilakukan dengan metode andragogi di mana peserta dirangsang melalui diskusi kelompok, dan juga diberi kesempatan mengutarakan pendapatnya selama berlangsungnya materi, 3. Antusiasme peserta terhadap pelaksanaan pengabdian ini adalah ketika dilakukan inisiasi pembentukan kelompok pengawas, mereka dengan cermat mengamatinya, serta sangat antusias dalam pembahasan bagaimana mekanisme pengawasan yang akan dilakukan.
\end{abstract}

Kata Kunci: Generasi Muda, Partisipasi, Pendidikan Politik

\begin{abstract}
Education is one means for transferring knowledge. With a variety of media used, it is expected to be able to provide the expected information. Political education is one of them, with the hope that people understand and understand what is meant by politics. Especially in rural communities where the tendency to have minimal information about politics. In this activity, political education uses the andragogy method, where learning is specifically for adults. Invite the community to play an active role in the problems that exist. Focus Group Discussion is one vehicle for community involvement, they can express their opinions. The main target in this activity is the youth group. The results of service are: 1. The implementation of "Political Education and Establishment of Village Fund Supervisory Groups" departs from two things, namely the first concerning the urgency of community participation in village governance. Second, departing from concerns about the tendency of community apathy in managing village funds, 2. The process of organizing this service is carried out by the andragogy method in which participants are stimulated through group discussions, and are also given the opportunity to express their opinions during the course of the material. is when initiating the formation of a superv isory group, they carefully observe it, and are very enthusiastic in discussing how the oversight mechanism will be carried out.
\end{abstract}

Keywords: A Young Generation, Participation, Political Education 


\section{PENDAHULUAN}

Pembangunan yang dilakukan oleh pemerintah Indonesia periode sekarang mencoba untuk lebih menyentuh pada ruang akar rumput. Dimana harapan yang dibawa agar terciptanya pembangunan yang merata serta hilangnya kesenjangan antara daerah, pemerintah mengupayakan untuk desa bangkit dan berkembang. Hal tersebut terlihat pada komitmen pemerintah dengan memberikan dana kepada masing-masing desa hingga menyentuh angka 1 miliar seperti yang tertuang dalam UU no 6 tahun 2014 tentang Desa dan PP no 8 tahun 2016 tentang Dana Desa bersumber dari APBN (Anonim, 2017). Dana desa disini dimaknai sebagai salah satu sumber pendapatan desa, dimana selain dana desa juga berasal dari bagian dari hasil PDRD Kabupaten/Kota, Alokasi dana desa dari Kabupaten/Kota, hingga hibah pihak ke-3 serta pendapatan terkait aset desa (UU nomor 6 tahun 2014 pasal 71 ayat 2), lebih lanjut pendapatan desa bersumber:

1. Pendapatan asli desa terdiri atas hasil usaha, aset, swadaya dan partisipasi, gotong royong, dan lain-lain yang bisa dianggap pendapatan desa.

2. Alokasi Anggaran Pendapatan dan Belanja Negara.

3. Bagian dari hasil pajak daerah dan retribusi daerah Kabupaten/Kota.

4. Alokasi dana desa yang merupakan bagian dari dana perimbangan yang diterima Kabupaten/Kota.

5. Bantuan keuangan dari Anggaran Pendapatan dan Belanja Daerah Provinsi dan Anggaran Pendapatan dan Belanja Daerah Kabupaten/Kota.

6. Hibah dan sumbangan yang tidak mengikat dari pihat ketiga.

7. Pendapatan lain-lain yang sah

Dengan adanya desentralisasi, memungkinkah adanya perubahan fundamental terkait hubungan antara daerah dan pusat, salah satunya adalah daerah mendapatkan keleluasaan untuk menghasilkan keputusan politik tanpa adanya intervensi dari pusat (Dwipayana, 2003). Desentralisasi lebih pada pengembangan otonomi daerah, namun selain konsep desentralisasi juga ada dekosentrasi yang berarti penyerahan wewenang pemerintahan oleh pemerintahan pusat kepada daerah otonom. Ada dua manfaat yang coba untuk diraih sebagai bentuk penerapan desentralisasi, yaitu pertama lebih mendorong terjadinya partisipasi, prakarsa, dan kreatifitas masyarakat terlibat dalam pembangunan disamping untuk pemerataan hasil pembangunan dengan memanfaatkan sumberdaya dan potensi yang tersedia. Kedua, perbaikan alokasi sumberdaya yang produktif melalui pergeseran peran pengambilan keputusan publik ke tingkat yang lebih rendah dan memiliki informasi yang lebih lengkap (Mardiasmo, 2002).

Struktur pemerintahan terendah adalah desa, dan desa masing-masing memiliki informasi yang detail serta akurat terkait kondisi daerahnya masing-masing. Sehingga dana desa yang diberikan oleh pemerintah pusat untuk lebih meningkatkan pembangunan masing-masing daerah

Pemerataan kemajuan yang ada akhirnya bisa untuk dinikmati secara merata kepada seluruh masyarakat Indonesia. Dana desa tersebut, bisa untuk meningkatkan kehidupan desa, memperbaiki sarana dan prasarana fisik, sebagai modal awal untuk lebih menghidupkan usaha desa yang akan menghasilkan profit kedepeannya.

Alokasi dana desa merupakan salah satu bentuk dari desentralisasi yang mendorong terbentuknya good governance, karena secara tidak langsung mendekatkan negara ke masyarakat dan sekaligus meningkatkan partisipasi masyarakat yang pada titik akhirnya mendorong akuntabilitas, transparasi dan responsivitas pemerintah lokal. Namun dana desa bukan hanya menampilkan cerita indah dan sukses dengan semakin majunya pembangunan yang ada di masing-masing daerah. Banyak juga masalah yang mengiringi terkait dana desa, mulai dari kurangnya pemahaman pejabat desa sebagai pemilik kewenangan dalam memanfaatkan dana desa, adanya penyelewengan dana desa, baik secara disengaja maupun tidak dikarenakan kurangnya pemahaman tadi, 
serta kurang adanya sistem yang mendukung keterlibatan masyarakat dalam proses pengelolaan dana desa.

Partisipasi masyarakat ini penting adanya, dimana dengan masrayakat aktif terlibat maka good governace terlihat hasilnya. Good Governance sendiri bisa diartikan sebagai tata kepemerintahan yang baik, dengan mengikuti kaidah-kaidah tertentu sesuai dengan prinsip dasarnya (Haryanto dan Arifuddin, 2007). Pelibatan masyarakat disini mencerminkan prinsip-prinsipnya, mulai dari akuntabilitas, transparansi, hingga partisipasi. Peletakan pondasi demokrasi itu penting, mengingat agar dana desa dapat dimaksimalkan untuk pembangunan daerahnya. Salah satu elemen massyarakat yang bisa aktif untuk kita libatkan adalah pemuda, dimana mereka memiliki semangat untuk ikut serta membangun daerah. Namun pengawasan yang ada tidak akan bisa berjalan dengan baik bila yang ada adalah kurangnya pemahaman akan dana desa.

Target luaran dalan pengabdian kepada masyarakat ini adalah: (1) pemahamana dana desa oleh seluruh masyarakat, (2) pembentukan kelompok pengawas dana desa oleh pemuda, dan (3) hasil program akan disebarluaskan dalam bentuk artikel yang dipublikasikan pada jurnal nasional atau prosiding atau media masa atau didaftarkan HaKI.

\section{METODE PELAKSANAAN}

Pelaksanaan dalam pengabdian ini adalah dilakukan observasi secara mendalam terkait dengan permasalahan dan juga pemahaman masyarakat terkait dengan dana desa. Observasi ini akan dapat diketahui permasalahan yang terjadi di desa Turus Kecamatan Gampengrejo Kabupaten Kediri. Pemilihan daerah tersebut berdasarkan pada observasi kecil terkait penggunaan dana desa yang tidak terserap dengan maksimal. Serta adanya berita terkait dengan tidak transparannya penggunaan dana desa.

Keterlibatann masyarakat dalam program pengabdian dilakukan dengan mengetahui keinginan masyarakat. Partisipasi masyarakat menjadi kunci penting keberhasilan dari program ini. Partisipasi masyarakat merupakan sebuah konsep yang telah berkembang dari waktu ke waktu. Pada tahun 1972, James V. Cunningham (Cunningham, 1972) mendefinisikan partisipasi sebagai "sebuah proses dimana individu-individu yang ada dimasyarakat dapat menyelesaikan permasalahan terkait generalisasi yang ada di masyarakat itu sendiri". Hardina (2006) mendukung gagasan bahwa partisipasi harus menjadi sarana ekspresi untuk orang yang paling terpinggirkan. Proses yang melibatkan mereka dalam manajemen dan produksi layanan yang mereka terima. Namun, sejak 1990, partisipasi masyarakat tidak lagi dilihat hanya sebagai sarana untuk mengintegrasikan berbagai kepentingan ke dalam sistem demokrasi, tetapi sebagai cara untuk memperbaiki fungsinya. Dalam pengembangan, partisipasi bisa dilihat sebagai "kehendak untuk mencapai proses transformasi sosial dari sudut pandang ekologi dan ekonomi; cara untuk mewujudkannya harus disesuaikan dengan konteks lokal (Callogero, 2017).

Partsipasi masyarakat sendiri dalam kaitanya dengan pembangunan sangatlah dibutuhkan. Bukan hanya sebagai wujud pelaksanaan demokrasi tetapi agar agar hasil pembangunan yang ditujukan untuk masyarakat dapat dihasilkan dengan tepat sasaran dan optimal. Menurut Adisasmita (2006), keterlibatan anggota masyarakat dalam pembangunan, yang meliputi kegiatan dalam perencanaan dan pelaksanaan (implementasi) suatu program/proyek pembangunan yang dikerjakan di dalam masyarakat lokal, dimaknai sebagai Partisipasi Masyarakat. Partisipasi ini merupakan salah satu bentuk Pemberdayaan Masyarakat (Social Empowerment) dalam rangka pemanfaatan dan pengelolaan sumber daya di lingkungan mereka tinggal, baik dari aspek masukan/input, aspek proses dan aspek keluaran/output. Dengan melibatkan masyarakat dalam suatu kegiatan pembangunan, dapat mempengaruhi keputusan yang diambil. Cornwall (2002) menjelaskan bahwa partisipasi akan memberi pengaruh dalam memutuskan kebijakan, 
sekaligus juga menciptakan sistem kontrol sosial yang menyangkut kehidupan masyarakat bersangkutan.

Metode yang dipakai dalam menumbuhkan partisipasi masyarakat adalah dengan mengadakan Focus Group Discussion. Disini diharapkan masyarakat akan dapat menyampaikan apa yang menjadi saran dan masukkan. Disamping itu juga dilakukan diskusi dan wawancara mendalam dengan para perangkat desa mengenai pembangunan yang telah dilakukan selama ini. Kedepannya akan ada seminar khusus yang menjadi semacam pelaporan terhadap masyarakat desa atas hasil dari program pengabdian yang telah kita laksanakan. Disana nantinya juga menjadi semacam inisisasi pembentukan kelompok pengawas dana desa.

Proses pembentukan kelompok ini diawali dengan melakukan hearing dan sosialisasi terhadap pemuda desa, dimana mereka yang selama ini apatis terhadap dana desa dan seluk beluk politik desa diajak untuk lebih peduli. Selain itu adalah dengan menggunakan media tokoh masyarakat, hal tersebut dimaksudkan untuk mendapatkan legitimasi dari masyarakat. Sehingga arah dari program ini akan berjalan dengan lancar. Pelibatan tokoh masyarakat diharapkan bisa menjadi dewan pembina sekaligus sebagai pembanding dari struktur pemerintahan desa.

Dalam proses sosialisasi dan juga diskusi rutin dengan pemuda, tim dibantu dengan beberapa mahasiswa menyebar keseluruh dusun yang ada disana. Sehingga mendapatkan data yang lebih komprhensif atas permasalahan yang ada di daerahnya. Pelibatan pemuda desa juga tidak hanya sebagai objek pengabdian, namun juga menjadi partner di lokasi. Mereka nantinya yang akan memberikan masukan kepada team, mana yang perlu dilakukan dan mana yang tidak, serta bagaimaana kondisi sosial politik yang ada disana juga berkat infromasi dari pemuda desa.

Pada akhir dari kegiatan pengabdian ini, ada seminar penyampaian hasil, dimana dalam seminar tersebut terbagi menjadi tiga materi, yaitu politik dan partisipasi, dana desa, dan kelompok civil society. Diakhir dari materi tersebut, nantinya akan diumumkan siapa saja yang terlibat dalam kelompok pengawas dana desa. Serta akan dilakukan inisiasi dan pengesahan oleh bapak kepala desa selaku pejabat pemerintah tertinggi yang ada di desa Turus Kecamatan Gampengrejo Kota Kediri.

Program ini mencoba untuk menselaraskan dengan visi dan misi Universitas Brawijaya terhadap desa. Dimana mencoba untuk menjadikan desa lebih mandiri dan membangun sebuah budaya entrepreneur desa, yang memanfaatkan dana desa sebagai sumber modalnya. Selain itu, kedepannya perlu adanya kerjasama antara fakultas atau jurusan ilmu politik yang ada di Universitas Brawijaya dengan Desa Turus Kecamatan Gampengrejo Kabupaten Kediri. Hal tersebut nantinya bisa menjadi desa binaan serta akan lebih dapat memantau program yang telah dibuat sebelumnya. Serta juga membuat kerjasama untuk lebih mengembangkan produk-produk lokal desa. Keuntungan yang didapatkan oleh institusi pendidikan salah satunya yang nyata adalah dapat menjadi lokasi mahasiswa untuk melakukakn praktek kerja magang. Serta bisa menjadi lokasi penelitian yang terkait dengan desa.

\section{HASIL DAN PEMBAHASAN}

Pemahaman pertama yang diperoleh bahwa Desa Turus kurang dapat memaksimalkan penggunaan dana desa. Sehingga produk-produk lokal yang ada di desa juga tidak berkembang dengan baik. Maka disusunlah team dengan melibatkan elemen desa, terutama pemuda desa untuk melacak potensi-potensi yang ada di daerah tersebut.

Data yang didapatkan tadi menjadi awal untuk membuat program yang tepat sasaran. Maka data yang didapatkan tadi disebarluaskan melalui FGD (Gambar 1). Pemanfaatan forum ini lebih kepada sebagai media untuk memberikan masukkan dan juga kritik atas apa yang telah dihasilkan. Sehingga kedepannya nanti program tersebut tidak berjalan dari satu sisi saja. 
Pengumpulan data terkait dengan potensipotensi yang ada di desa melalui survey sederhana yang mengambil sampel dari desa Turus. Pemuda desa disini bertindak sebagai enumerator dan tim dari Brawijaya sebagai supervisi serta yang menganilisis data lapangan tersebut. Beberapa contoh hasil dari survey, mendapatkan masyarakat mengharapkan adanya upaya pemasaran produk lokal dan pembangunan pasar lebih baik lagi. Juga ada keinginan dalam membangun pariwisata air mini yang memanfaatkan sumber mata air desa setempat. Pemanfaatan sumber mata air tersebut menjadi salah satu temuan yang menarik dan perlu ada kajian yang lebih mendalam terkait dengan pembangunan wisata desa sebagai salah satu media pemnfaatan dana desa.

Desa Turus Kecamatan Gampengrejo juga memiliki potensi lain, yaitu lahan pertanian yang bisa dikelola secara swadaya masyarakat. Sehingga disini, masyarakat menjadi berdaya atas potensi yang dimiliki oleh desa tersebut. Diskusi dan wawancara dilakukan dengan perangkat desa, mulai dari kepala desa hingga staff di kantor desa. Hal tersebut berupaya untuk mencari informasi terkait dengan transparansi dana desa. Dimana hasilnya nanti akan dikomparasikan dengan data survey yang dilakukan diawal. Harapannya adalah akan mengetahui bagaimana pelaksanaan pembangunan desa dengan dana desa ini sudah sesuai dengan prinsip good governance atau tidak.

Dari hasil wawancara, tidak menunjukkan bahwa keselurahan pegawai yang ada di kantor desa memahami dengan betul bagaiamana dana desa tersebut dijalankan. Mereka juga cenderung apatis, hal tersebut menjadi sangat wajar dimana keterbukaan informasi itu tidak dilakukan oleh kepala desa kepada jajaran dibawahnya. Indikasi ini ternyata juga sama, bahwa transparansi dana desa tidak bisa diakses oleh masyarakat dan hanya dimiliki oleh beberapa perangkat saja. Sehingga masyarakat juga cenderung apatis terhadap pembangunan yang ada di desanya.

Beberapa pemuda terlibat dalam tim juga telah menyadari adanya sekat informasi tersebut, namun mereka kesulitan menemukan caranya untuk mengakses informasi yang ada. Budaya sungkan dan keengganan menjadi troublrmaker menjadikan mereka cenderung tidak mau tahu dengan dana desa. Sehingga pelibatan mereka selain sebagai bentuk partisipasi juga unutk menumbuhkan kesadaran mereka.

Diskusi menjadi media yang sangat penting, mulai dari awal menetukan objek dari program hingga sampai pemantapan hasil dari program (Gambar 2). Diskusi juga dipakai sebagai wadah dalam menggodok pembentukan kelompok pemuda pengawasa dana desa. Mulai dari pembentukan visi-misi, nama dan bentuk organisasinya. Ada beberapa yang memberikan saran untuk dijadikan satu dengan organisasi kepemudaan yang sudah ada, ada juga yang berharap berdiri sendiri, dengan alasan untuk netralitas dan juga pemenuhan anggota kelompok yang tidak berasal dari ormas kepemudaan desa.

Kelompok ini disosialisasikan berbarengan dengan seminar laporan program pengabdian masyarakat. Dalam pelaporan tersebut, dibagi menjadi tiga sesi, yaitu terkait dengan program pendidikan politik, inisisasi kelompok dan masukkan dari para elemen masyarakat desa yang hadir sebagai tambahan laporan dalam program yang telah dilakukan.

Inisiasi kelompok pengawas dana desa berjalan dengan baik. Kelompok pengawas dana desa hanya masih berupa nama ketua kelompok serta visi-misi nya. Nama ketua kelompok tersebut adalah Budiono, yang juga merupakan salah satu pemuda yang aktif dalam mengawasi pembangunan yang dilakukan oleh desa.

Visi kelompok tersebut adalah sebagai berikut:

1. Meningkatnya peran masyarakat dalam pembangunan.

2. Kebijakan-kebijakan pemerintah desa dalam penyelengaraan pemerintahan desa lebih baik.

3. Pembangunan desa yang lebih berkualitas.

4. Kesejahteraan masyarakat meningkat. 
Sedangkan misinya adalah sebagai berikut:

1. Pemerintahan desa menjadi lebih efisien, efektif, dan bersih dengan mengedapankan peran masyarakat.

2. Melakukan pengawasan terhadap program dan juga pembangunan yang ada di desa.

3. Melakukan pemberdayaan masyarakat dan pembangunan desa dengan jalinan kemitraan.

4. Meningkatnya kualitas sumber daya manusia dalam pembangunan desa yang berkelanjutan.

5. Mengembangkan potensi-potensi perekonomian yang ada di desa.

Beberapa hal yang dirasa masih kurang adalah, jalinan komunikasi yang kurang baik antara perangkat desa dengan masyarakat, sehingga menimbulkan jarak antar mereka. Hal tersebut sangat tidak baik, dimana kebutuhan masyarakat atas pelayanan yang diberikan oleh pemerintahan desa tidak didapatkan dengan maksimal.

Kerterlibatan masyarakat juga sangat kurang, hal tersebutlah sebenarnya yang menjadikan pembentukan kelompok pengawasa dana desa menjadi sangat penting. Dimana dengan adanya kelompok tersebut, diharapkan menjadi media dalam mendapatkan informasi terkait dengan program dan pembangunan desa.

Selebihnya, perlu ada program lanjutan, dimana terkait dengan evaluasi dari kelompok yang sudah di inisiasi tadi. Serta perlu adanya perluasan kerjasama, sehingga pemerintah desa bisa menjadikan Universtisa Brawijaya sebagai mitra dalam melakukan pembangunan yang lebih baik. Dengan adanya kerjasama tersebut, maka tidak hanya FISIP saja yang bisa jadi pendamping, dan dapat menggali potensi-potensi yang ada.

\section{Tahapan Program}

Program kegiatan Pengabdian Masyarakat di Desa Turus Kecamatan Gampengrejo Kabupaten Kediri dapat dilihat secara ringkas pada Tabel 1 dan 2.
Bulan: Agustus 2018

\begin{tabular}{|c|c|l|l|}
\hline No. & Tanggal & Kegiatan & \multicolumn{1}{|c|}{$\begin{array}{c}\text { Catatan } \\
\text { Kemajuan }\end{array}$} \\
\hline 1. & $1 \mathrm{~s} / \mathrm{d} 10$ & $\begin{array}{l}\text { Diskusi } \\
\text { pembahasan } \\
\text { objek } \\
\text { pengabdian } \\
\text { masyarakat }\end{array}$ & $\begin{array}{l}\text { Diskusi tentang } \\
\text { masalah- } \\
\text { masalah dan } \\
\text { juga potensi } \\
\text { daerah yang } \\
\text { akan dituju }\end{array}$ \\
\hline 2. & $\begin{array}{c}11 \mathrm{~s} / \mathrm{d} \\
17\end{array}$ & $\begin{array}{l}\text { Pengumpulan } \\
\text { data program }\end{array}$ & $\begin{array}{l}\text { Survey dan } \\
\text { wawancara }\end{array}$ \\
\hline 3. & $21 \mathrm{~s} / \mathrm{d}$ \\
25 & $\begin{array}{l}\text { Proses } \\
\text { analisis data } \\
\text { lapangan }\end{array}$ & $\begin{array}{l}\text { Membuat list } \\
\text { yang terkait } \\
\text { dengan } \\
\text { permasalahan } \\
\text { dan potensi } \\
\text { yang ada di } \\
\text { daerah tersebut }\end{array}$ \\
\hline 4. & $26 \mathrm{~s} / \mathrm{d}$ \\
27 & FGD & $\begin{array}{l}\text { Pemparan hasil } \\
\text { survey dan } \\
\text { wawancara }\end{array}$ \\
\hline
\end{tabular}

Bulan: September 2018

\begin{tabular}{|c|c|c|l|}
\hline No. & Tanggal & Kegiatan & \multicolumn{1}{c|}{$\begin{array}{c}\text { Catatan } \\
\text { Kemajuan }\end{array}$} \\
\hline 1. & $1 \mathrm{~s} / \mathrm{d} 10$ & $\begin{array}{l}\text { Diskusi dengan } \\
\text { pemuda dan } \\
\text { elemen } \\
\text { pembentukan } \\
\text { pasyarakat } \\
\text { lainnya terkait } \\
\text { dengan } \\
\text { pembentukan } \\
\text { kelompok dana } \\
\text { desa }\end{array}$ \\
\hline 2. & $11 \mathrm{~s} / \mathrm{d}$ & $\begin{array}{l}\text { Membuat } \\
\text { laporan hasil } \\
\text { program } \\
\text { pengabdian }\end{array}$ & $\begin{array}{l}\text { Penulisan hasil } \\
\text { dan } \\
\text { pembahasan } \\
\text { program } \\
\text { pengabdian }\end{array}$ \\
\hline 3. & 22 & $\begin{array}{l}\text { Seminar hasil } \\
\text { hasil }\end{array}$ & $\begin{array}{l}\text { dan inisiasi } \\
\text { kelompok } \\
\text { pengawas dana } \\
\text { desa. }\end{array}$ \\
\hline
\end{tabular}




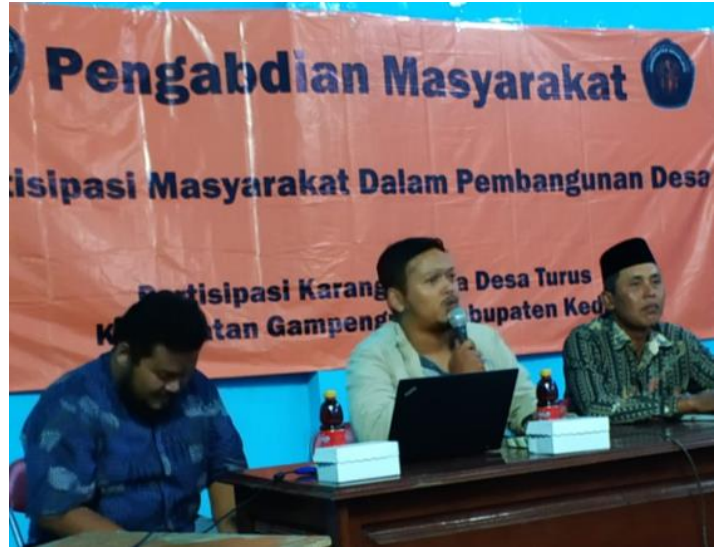

Gambar 1. Kegiatan FGD yang Dilakukan oleh Tim

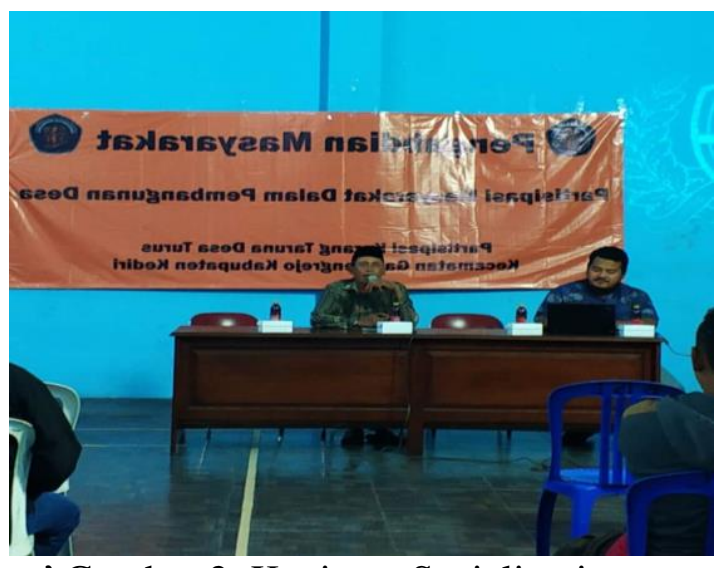

' Gambar 2. Kegiatan Sosialisasi yang Dilakukan oleh Tim

\section{KESIMPULAN}

Kesimpulan dari kegiatan di Desa Turus Kecamatan Gampengrejo Kabupaten Kediri adalah:

1. Penyelenggaraan "Pendidikan Politik dan Pembentukan Kelompok Pengawas Dana Desa" berangkat dari dua hal, yakni pertama mengenai urgensi Partisipasi masyarakat dalam pemerintahan desa. Kedua, berangkat dari keprihatinan terhadap kecenderungan apatis masyarakat dalam pengelolahan dana desa.

2. Proses penyelenggaraan pengabdian ini dilakukan dengan metode andragogi di mana peserta dirangsang melalui diskusi kelompok, dan juga diberi kesempatan mengutarakan pendapatnya selama berlangsungnya materi. Metode ini dipilih agar peserta mampu menyelami urgensi dari materi yang disampaikan.

3. Antusiasme peserta terhadap pelaksanaan pengabdian ini adalah ketika dilakukan inisiasi pembentukan kelompok pengawas, mereka dengan cermat mengamatinya, serta sangat antusias dalam pembahasan bagaimana mekanisme pengawasan yang akan dilakukan.

\section{REFERENSI}

Adisasmita R., (2006), Membangun Desa Partisipatif. Yogyakarta: Graha Ilmu.

Anonim, (2017), Buku pintar dana desa (desa-desa untuk kesejahteraan rakyat), Kementrian Keuangan: Jakarta.

Callogero A., (2017), A Participatory Approach to Urban Planning in Slum Neighbourhoods of the Metropolitan Area of Port-au-Prince. French: Urban Crises Learning Partnership.

Cornwall A., (2001), Making spaces, changing places: situating participation in development. IDS Working Paper 170. England: Institute of Development Studies

Cunningham J. V., 1972 Citizen Participation in Public Affairs. Public Administration Review 32 (Oktober).

Dwipayana A. S. E., (2003), Membangun Good Governance di Desa, Institute of Reseach and Empowerment, Yogyakarta.

Hardina D., (2006), An Empowering Approach to Managing Social Service Organizations, Springer Publishing Company, New York, Amerika Serikat

Haryanto S. dan Arifuddin, 2007, Akutansi Sektor Publik, edisi pertama: Universtias Diponegoro Semarang.

Mardiasmo, 2002, Otonomi Daerah dan Manajemen Keuangan Daerah, Andi Yogyakarta. 
VOL. 03. NO. 1, JANUARI 2019

Peraturan Pemerintah Nomor 8 tahun 2016 tentang Dana Desa.

Undang-Undang Nomor 6 Tahun 2014 tentang Desa. 